AMERICAN JOURNAL OF FOOD AND NUTRITION

Print: ISSN 2157-0167, Online: ISSN 2157-1317, doi:10.5251/ajfn.2011.1.2.49.54

(C) 2011, ScienceHuß, http://www.scihub.org/AJFN

\title{
Nutrient, antinutrient, mineral and zinc bioavailability of okra Abelmoschus esculentus (L) Moench Variety
}

\author{
${ }^{1}$ F.O. Adetuyi, ${ }^{2}$ A.U. Osagie and ${ }^{3}$ A.T. Adekunle \\ ${ }^{1}$ Department of Food Science and Technology, Rufus Giwa Polytechnic, Owo, Nigeria \\ ${ }^{2}$ Department of Biochemistry, ${ }^{3}$ Department of Crop Science, University of Benin, Benin City, \\ Nigeria
}

\begin{abstract}
The different local okra varieties (Benin, Auchi, Ikaro, Akure, Okene and Lokoja) sold and consumed in Ifon, Ose Local Government area of Ondo State Nigeria were evaluated with regards to the nutrients, antinutrients, minerals and zinc bioavailability. The result of the study revealed that the protein content of the varieties ranges between $13.61-16.27 \%$ with Ikaro variety having the highest protein content. The fiber and fat contents ranges from $10.15-11.63 \%$ and $9.03-10.57 \%$ respectively. Okene variety was observed to have the highest content in both fiber and fat contents. The phytate content in the local okra varieties varies from $2.64-3.90 \%$. Auchi variety had the highest content of phytate which was not significantly $(P<0.05)$ different from the phytate content of Benin variety. The saponin content ranges from $0.470-0.612 \%$ while the oxalate $0.324-0.506 \%$. The viscosity of the local okra varieties ranges between $56.42-$ $68.12 \mathrm{Cp}$ with lkaro local okra having the highest viscosity. The mineral content ranges from 1.29$1.37 \mathrm{mg} / 100 \mathrm{~g}$ (Zinc); $0.87-0.96 \mathrm{mg} / 100 \mathrm{~g}$ (Iron); 51.08-51.18mg/100g (Magnesium); 58.22-58.31 $\mathrm{mg} / 100 \mathrm{~g}$ (Calcium) and 62.05-62.17 mg/100g (Phosphorous). There was no significant $(\mathrm{P}<0.05)$ difference in the magnesium, calcium and phosphorus contents of all the varieties. The calculated [Ca][Phytate]/[Zn] molar ratio was $0.293-0.436 \mathrm{~mol} / \mathrm{kg}$. Ikaro okra variety recorded the least value in [Ca][Phytate]/[Zn] (0.293) while Auchi variety had the highest value in [Ca][Phytate]/[Zn] (0.436). It could therefore be concluded that the local okra varieties consumed in Ifon are of good nutritional qualities but Ikaro local okra variety had a better nutritional quality considering protein, fiber, ash and viscosity as quality indices. Also the zinc in this variety is more bio-available because it exhibits the least [Ca][Phytate]/[Zn] molar ratio.
\end{abstract}

Keywords: Okra, mineral, Zn bioavailability, antinutrient

\section{INTRODUCTION}

Okra Abelmoschus esculentus (L) Moench is a tall annual dicotyledonous plant related to cotton and thought to be of African origin. It is still found growing wild along the River Nile in Egypt as well as in Ethiopia (Kochhar, 1986). French colonialist carried okra to the new world soon after 1700 . Now it is a widely grown vegetable crop in the tropics and subtropics and also in the warmer temperate areas (Kochhar, 1986).

Okra is also called Ochro, Okro, Lady's finger, Gumbo, Vendakai (India), Kachieb (Thailand), Ila Yoruba (Nigeria). It is of different cultivars, which vary in time of planting to maturity, colour of leaves, stem length, shape of fruit and other characters (Tindall, 1983). Okra is traditionally grown in a region which includes the following countries: Cote d Ivoire, Ghana, Nigeria, Egypt, Sudan, Burkinafaso, Togo, Cameroon, Tanzania, Zambia and Zimbabwe. The most important production regions are in Ghana, Burkinafaso and Nigeria. In Africa there is great diversity of okra (De Lannoy, 2001).

Young pods may be harvested 60-180 days from sowing, about 5-10 days after flowering depending on the cultivar grown. Much work has been done on the effect of maturation of okra when still attached to the parent plant and also on the nutritional and antinutritional qualities of fresh okra (Sowunmi and Chukwudebe 1979, Haytowitz and Mathews 1984, Omueti and Adepoju 1988, Oseni 1990).

Okra fruit can be dried whole or sliced and subsequently conserved. Before selling, the dried product is usually ground to a powder (Siemonsma and Kouame, 2004). Okra can also be preserved by fermentation carried out at $30^{\circ} \mathrm{C}$ (Kotzekidou and Roukas, 1986). The fresh and green tender fruits are used as vegetable. The tender and edible fruits are easily cut by the kitchen knife and set into 
mucilaginous consistency after cooking. (Sowunmi and Chukwudebe, 1979). Okra mucilage has medicinal applications when used as a plasma replacement or 'blood - volume expander.' The mucilage of okra binds cholesterol and bile acid carrying toxins dumped into it by the liver. Okra also has industrial applications and is used in confectionary (Siemonsma and Kouame, 2004; Kochhar, 1986 and Schalau, 2002)

Okra is a powerhouse of valuable nutrients, nearly half of which is soluble fibre in the form of gums and pectins which help to lower serum cholesterol, reducing the risk of heart diseases. The other half is insoluble fibre, which helps to keep the intestinal tract healthy (Schalau, 2002).

It is well known that zinc is one of the essential trace elements for human nutrition (Kono and Yoshida 1989). Children, however, appear to be more vulnerable to sub-optimal zinc status, presumably because of their high zinc requirements for growth. The importance of a foodstuff as a source of dietary zinc depends upon both the total zinc content and the level of other constituents in the diet that affect zinc bioavailability. Phytic acid may reduce the bioavailability of dietary zinc and calcium by forming insoluble mineral chelate at physiological $\mathrm{pH}$. The inhibitory effect of phytate on zinc absorption has been quantified by the molar ratios of phytate to zinc in the diet. Ratios greater than 20 have been associated with biochemical and/or clinical evidence of zinc deficiency, Calcium potentiates the inhibitory effect of phytate on zinc absorption, even at relatively low amounts of dietary phytate (Akindahunsi and Oboh 1999).

The site of production of these okra are always very far to the market and where they are been consumed, therefore post-harvest deterioration of fresh okra result in loss of produce due to the poor storage and transport conditions employed by farmers in bringing the produce from the farms in outlying villages to the city markets (Adetuyi et al 2008). The aim of this work is to evaluate the nutrients, minerals, antinutrients and zinc bioavailability of the different local okra varieties sold and consumed in Ifon, Ose Local Government area of Ondo State Nigeria.

\section{MATERIALS AND METHODS}

The local okra varieties namely Benin, Auchi, Ikaro, Akure, Okene and Lokoja were freshly harvested from a pilot farm in Benin City Nigeria. The chemicals were analytical grade while the water used in the analysis was glass distilled.

Sample analysis: Freshly harvested local okra varieties were analyzed with regards to the nutrients, antinutrients, minerals and zinc bioavailability. The Okra were sliced and dried in the oven at $45^{\circ} \mathrm{C}$ to a constant weight before the analysis. The nutrient composition, (moisture, crude fibre, ash and fat) of the local okra were determined using the standard AOAC (1990) method, the protein content was determined using the micro-kjeldhal method ( $N \times 6.25)$ The minerals were determined on aliquots of the solutions of the ash by established flame atomic absorption spectrophotometry method using atomic absorption spectrophotometer (model 372) (Perkin Elmer, 1982). The phytate content was determined by the method of Maga, (1982), this depends on the ability of standard ferric chloride to precipitate phytate in dilute hydrochloric acid extract of the Okra. The Saponin was determined using the spectrophotometric method of Brunner, (1984), in which the mixture of okra and Isobutyl alcohol $(2 \mathrm{~g}$ in $250 \mathrm{ml}$ isobutyl alcohol) was filtered into $20 \mathrm{ml} 40 \%$ saturated solution of magnesium carbonate. The mixture is filtered to get a colorless solution, $2 \mathrm{ml}$ of $5 \%$ iron (iii) chloride is added to $1 \mathrm{ml}$ of the colorless solution and made up to $50 \mathrm{ml}$ mark with distilled water and the absorbance was measured after 30 minuties at $380 \mathrm{~nm}$. The oxalate content was determined by the method of AOAC (1990). The method of Ferguson et al (1988) was used for the calculation of phytate : zinc, calcium : phytate and [Ca] [phytate]/ [Zn] molar ratios and used for the $\mathrm{Zn}$ bioavailability prediction.

Analysis of data: Data Collected were subjected to the analysis of variance (SAS, 2002). Mean separation were done where there was significant differences using Duncan multiple range test procedure as described in the SAS soft ware. Significance was accepted at $P<0.05$.

\section{RESULTS AND DISCUSSION}

The nutrient content of the local okra varieties is presented in Table 1; the table revealed that the protein content ranges between $13.61-16.27 \%$. The protein content of of the local okra varieties were in the same range of the protein reported for INDIANA okra variety (Agbo et al 2008). Okra can be considered a high protein vegetable when compared with Talinum triagulare, Amarantus hybridus and Celosia argentia (Oguntona, 1998). Auchi variety had the least protein content while Ikaro variety had the 
highest; this could be due to genetic factor. However there was no significant $(P<0.05)$ difference in the protein content of Ikaro and Okene variety. The fiber and fat contents ranges from $10.15-11.63 \%$ and $9.03-10.57 \%$ respectively. The fiber content of okra is high when compared with Amarantus hybridus $1.6 \%$ and Laurea taraxifolia $2.0 \%$ but very low in comparism with Gnetumn africanum 33.0\% (Oguntona 1998). Okene variety was observed to have the highest content in both fiber and fat contents. The ash content in the okra varieties varies from 7.19 - 9.63\%. The ash contents in these varieties were in the range of the values reported for Vernonia amygdalina 9\% and Corchorus olitorius $10 \%$ (Oguntona 1998). Ikaro variety recorded the highest ash content but it was not significantly $(\mathrm{P}<0.05)$ different from all other varieties. Phytate is a very stable and potent chelating food component that is considered to be an antinutrient by virtue of its ability to chelate divalent minerals and prevent their absorption (Oboh 2006). The phytate content in the local okra varieties is reported in Table 2 . It varies from $2.64-3.90 \%$. Auchi variety had the highest content of phytate which was not significantly $(P<0.05)$ different from the phytate content of Benin variety. The phytate in these okra varieties were in the same range of phytic acid reported for Nigerian vegetable (Udosen and Ukpanah 1993). The saponin content ranges from $0.470-0.612 \%$ while the oxalate $0.324-0.506 \%$. There was no significant $(P<0.05)$ difference in the saponin content of Benin and Auchi varieties though Benin variety recorded the highest content in saponin. The viscosity of the local okra varieties is presented in Figure 1. It showed the range of viscosity to be $56.42-68.12 \mathrm{Cp}$ with Ikaro local okra having the highest viscosity of $68.12 \mathrm{Cp}$ which was significantly $(P<0.05)$ higher than other varieties observed. It is expected that the higher the moisture content the higher the viscosity which could have been contributed to Ikaro local okra having the highest viscosity. The mineral content of the local okra varieties is shown in Table 3 . The mineral content ranges from $1.29-1.37 \mathrm{mg} / 100 \mathrm{~g}$ (Zinc); 0.87 $0.96 \mathrm{mg} / 100 \mathrm{~g} \quad$ (Iron); $51.08-51.18 \mathrm{mg} / 100 \mathrm{~g}$ (Magnesium); $58.22-58.31 \mathrm{mg} / 100 \mathrm{~g}$ (Calcium) and 62.05-62.17 mg/100g (Phosphorous). The mineral contents of these okra varieties were in the range of minerals reported for Nigerian leafy vegetables (Oguntona, 1998 and Aletor and Adeogun 1995). Table 3 also revealed that there was no significant $(P<0.05)$ difference in the magnesium, calcium and phosphorus contents of all the varieties. It is to be noted that Okene variety had the highest zinc content but was not significantly $(P<0.05)$ different from that of Lokoja variety. The calculated phytate : zinc, calcium : phytate and [Ca][Phytate]/[Zn] molar ratios are presented in Table 4. The phytate : zinc molar ratio (20.2-30.0). These values were above the considered critical value of 15.0 (Fergusson et al 1988). The indication of this is that the phytate content will reduce the bioavailability of zinc to a critical level in all these local okra varieties. However the calculated calcium : phytate molar ratio (2.503.63) were below 6.0. As reported by Oboh et al (2005) the solubility of phytate and proportion of zinc bound to the complex depend on the dietary calcium levels. Therefore phytate precipitation is not complete until dietary calcium : phytate molar ratios attain a value of approximately 6.0. At lower ratios, phytate precipitations are incomplete causing some dietary zinc to remain in solution. The calculated [Ca][Phytate]/[Zn] molar ratio is considered a better index for predicting zinc bioavailability compared with the phytate:zinc ratio because of the calcium to phytate interaction (Oberleas 1973 and Akindahunsi and Oboh 1999). The calculated [Ca][Phytate]/[Zn] molar ratio $(0.293-0.436 \mathrm{~mol} / \mathrm{kg})$ were below the critical level $(0.5 \mathrm{~mol} / \mathrm{kg})$, an indication of bioavailability of dietary zinc (Davies and Warrington, 1986). Ikaro okra variety recorded the least values in phytate : zinc (20.2) and [Ca][Phytate]/[Zn] (0.293) but highest in calcium:phytate (3.63). Auchi variety had the highest values in phytate : zinc (30.0) and [Ca][Phytate]/[Zn] (0.436) while Benin and Auchi varieties had the lowest in calcium:phytate (2.50). The variations in the calculated [Ca][Phytate]/[Zn] for the different okra varieties could be attributed to genetic or varietal differences. The [Ca][Phytate]/[Zn] molar ratio obtained for the different local okra varieties were lower to the value obtained for water leaf (5.2) and spinach (2.1) (Akindahunsi and Oboh 1999) but higher than the value reported by Ola and Oboh (2001) for various species of mushrooms (0.01$0.20 \mathrm{~mol} / \mathrm{kg}$ ). 
Table 1: Nutrient content of local okra variety in \%

\begin{tabular}{|l|l|l|l|l|l|}
\hline Variety & Moisture content & Protein & Fibre & Fat & Ash \\
\hline Benin & $88.73 \mathrm{a}$ & $14.87 \mathrm{~b}$ & $10.63 \mathrm{~b}$ & $9.67 \mathrm{~b}$ & $8.26 \mathrm{a}$ \\
\hline Auchi & $87.59 \mathrm{~b}$ & $13.61 \mathrm{~b}$ & $10.15 \mathrm{~b}$ & $9.82 \mathrm{~b}$ & $7.19 \mathrm{a}$ \\
\hline Ikaro & $90.13 \mathrm{a}$ & $16.27 \mathrm{a}$ & $11.18 \mathrm{~b}$ & $9.03 \mathrm{~b}$ & $9.63 \mathrm{a}$ \\
\hline Akure & $89.02 \mathrm{a}$ & $15.17 \mathrm{~b}$ & $10.93 \mathrm{~b}$ & $9.97 \mathrm{~b}$ & $8.56 \mathrm{a}$ \\
\hline Okene & $89.63 \mathrm{a}$ & $15.77 \mathrm{a}$ & $11.63 \mathrm{a}$ & $10.57 \mathrm{a}$ & $9.16 \mathrm{a}$ \\
\hline Lokoja & $88.35 \mathrm{~b}$ & $14.41 \mathrm{~b}$ & $10.28 \mathrm{~b}$ & $9.22 \mathrm{~b}$ & $7.89 \mathrm{a}$ \\
\hline
\end{tabular}

Values represent mean of triplicate.

Values with the same letter along the column are not significantly different $(P<0.05)$

Table 2: Antinutrient content of local okra variety in \%

\begin{tabular}{|l|l|l|l|}
\hline Variety & Phytate & saponin & oxalate \\
\hline Benin & $3.84 \mathrm{a}$ & $0.612 \mathrm{a}$ & $0.462 \mathrm{a}$ \\
\hline Auchi & $3.90 \mathrm{a}$ & $0.610 \mathrm{a}$ & $0.464 \mathrm{a}$ \\
\hline Ikaro & $2.64 \mathrm{~b}$ & $0.470 \mathrm{c}$ & $0.495 \mathrm{a}$ \\
\hline Akure & $2.97 \mathrm{~b}$ & $0.516 \mathrm{~b}$ & $0.506 \mathrm{a}$ \\
\hline Okene & $3.06 \mathrm{~b}$ & $0.561 \mathrm{~b}$ & $0.391 \mathrm{~b}$ \\
\hline Lokoja & $3.12 \mathrm{~b}$ & $0.523 \mathrm{~b}$ & $0.324 \mathrm{~b}$ \\
\hline
\end{tabular}

Values represent mean of triplicate.

Values with the same letter along the column are not significantly different $(P<0.05)$

Table 3: Mineral content of local okra variety in $\mathrm{mg} / 100 \mathrm{~g}$

\begin{tabular}{|l|l|l|l|l|l|}
\hline Variety & Zinc & Iron & Magnesium & Calcium & Phosphorus \\
\hline Benin & $1.31 \mathrm{~b}$ & $0.90 \mathrm{a}$ & $51.12 \mathrm{a}$ & $58.27 \mathrm{a}$ & $62.11 \mathrm{a}$ \\
\hline Auchi & $1.29 \mathrm{~b}$ & $0.87 \mathrm{~b}$ & $51.08 \mathrm{a}$ & $58.22 \mathrm{a}$ & $62.05 \mathrm{a}$ \\
\hline Ikaro & $1.30 \mathrm{~b}$ & $0.88 \mathrm{~b}$ & $51.09 \mathrm{a}$ & $58.23 \mathrm{a}$ & $62.06 \mathrm{a}$ \\
\hline Akure & $1.33 \mathrm{~b}$ & $0.93 \mathrm{a}$ & $51.13 \mathrm{a}$ & $58.29 \mathrm{a}$ & $62.14 \mathrm{a}$ \\
\hline Okene & $1.37 \mathrm{a}$ & $0.96 \mathrm{a}$ & $51.18 \mathrm{a}$ & $58.31 \mathrm{a}$ & $62.17 \mathrm{a}$ \\
\hline Lokoja & $1.36 \mathrm{a}$ & $0.94 \mathrm{a}$ & $51.14 \mathrm{a}$ & $58.30 \mathrm{a}$ & $62.15 \mathrm{a}$ \\
\hline
\end{tabular}

Values represent mean of triplicate.

Values with the same letter along the column are not significantly different $(P<0.05)$

Table 4: Calculated phy:Zn, Ca:phy and[Ca][phy]/[Zn] molar ratios of local okra variety

\begin{tabular}{|l|l|l|l|}
\hline Variety & Phytate $:$ Zn & Ca : Phytate & {$\left[\right.$ Ca] $[$ Phytate $] /[\mathrm{Zn}]^{\mathrm{x}}$} \\
\hline Benin & 29.1 & 2.50 & 0.423 \\
\hline Auchi & 30.0 & 2.50 & 0.436 \\
\hline Ikaro & 20.2 & 3.63 & 0.293 \\
\hline Akure & 22.2 & 3.23 & 0.322 \\
\hline Okene & 22.3 & 3.13 & 0.324 \\
\hline Lokoja & 22.7 & 3.08 & 0.331 \\
\hline
\end{tabular}

${ }^{\mathrm{x}} \mathrm{mol} / \mathrm{kg}$ 


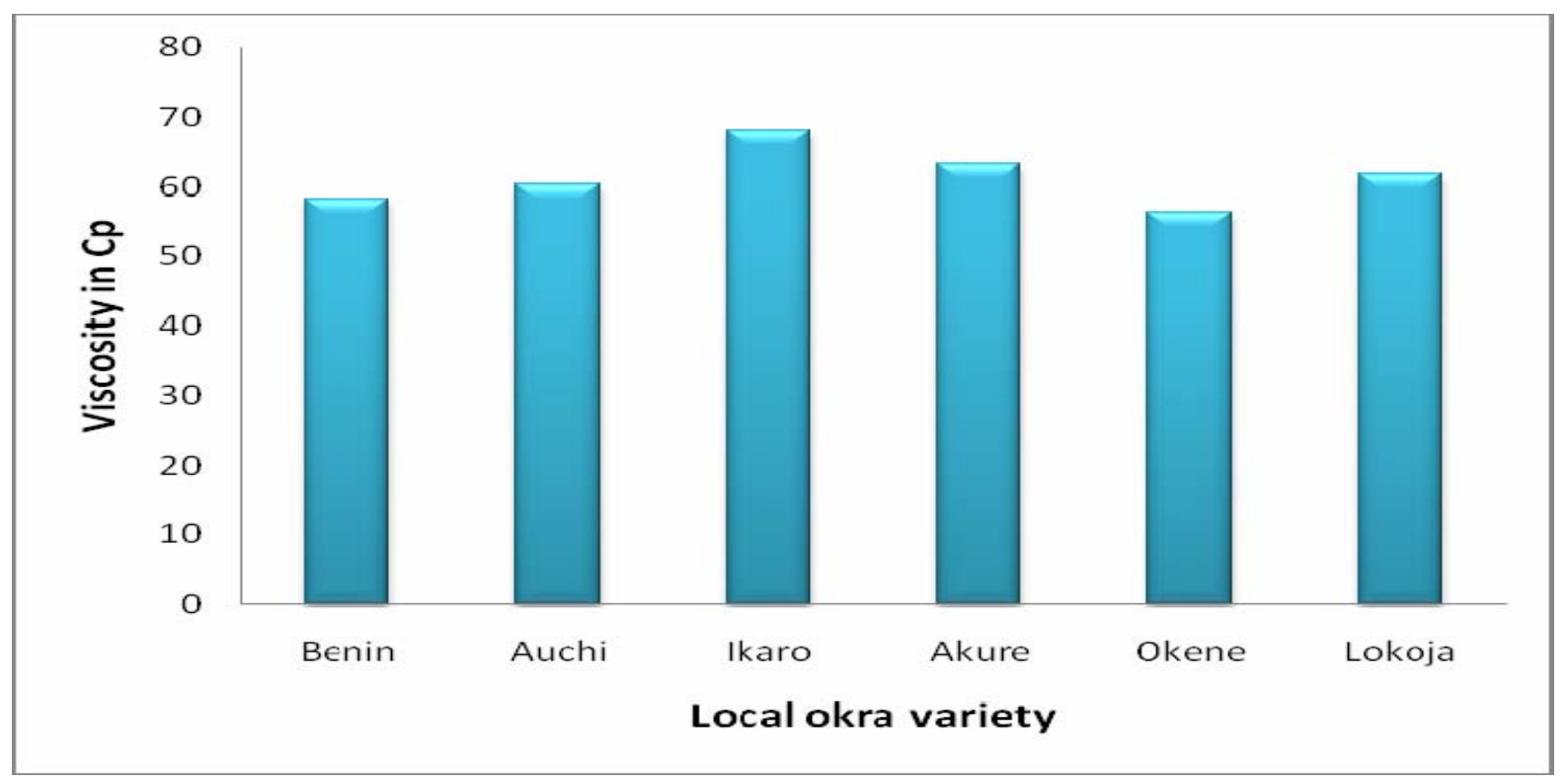

Fig 1: Viscosity content of local okra variety in Cp

\section{CONCLUSION}

It could therefore be concluded that the local okra varieties consumed in Ifon are of good nutritional qualities but Ikaro local okra variety had a better nutritional quality considering protein, fiber, ash and viscosity as quality indices. Also the zinc in this variety is more bio-available because it exhibits the least [Ca][Phytate]/[Zn] molar ratio.

\section{REFERENCES}

Adetuyi F.O, Osagie A.U and Adekunle A.T (2008) Effect of Postharvest Storage Techniques on the Nutritional Properties of Benin Indigenous Okra Abelmoschus esculentus (L) Moench Pakistan Journal of Nutrition 7 (5): 652-657

Akindahunsi A.A and Oboh G (1999) Effect of some postharvest treatments on the bioavailability of zinc from some selected tropical vegetables. La Rivista Italiana Delle Grasse 76, 285-287

Agbo A.E, Gnakri D, Beugré M. G, Fondio L and Kouamé C (2008) Maturity degree of four Okra fruits varieties and their nutrients composition. Electronic Journal of Food and Plants Chemistry 3 (1): 1-4

Aletor M.V.A and Adeogun O.A (1995) Nutrient and antinutrient componentsof some tropical leafy vegetables. Food Chemistry. 53: 375-379

A.O.A.C (1990). Official method of Analysis. Association of official Analytical chemists, food composition, additives natural contaminant. Adrich RC (ed) Vol 2, 15th ed. Association of official Analytical chemist Inc U.S.A

Brunner, J. H (1984). Direct spectrophotometric determination of saponin .Anal. Chem. 34: 1314 1326.

Davies, N.T and Warrington, S (1986) The phytic acid, mineral, trace element, protein and moisture content of UK Asian immigrant foods. Human NutritionApplied Nutrition 40A, 49-59

De Lannoy, G (2001) Vegetables. In: Crop production in Tropical Africa. Editor: Roman H. Raemaekers. Directorate General for International co-operation (DGIC) Brussels, Belgium 453-458

Ferguson E.L, Gibson R.S, Lilian, T.U, Berry N, and Ounpuu, S(1988) Phytate, zinc and calcium content of 30 East Africa foods and their calculated phytate : $\mathrm{Zn}$, $\mathrm{Ca}$ : phytate and [Ca] [phytate]/ [Zn] molar ratios. Journal of Food Composition and Analysis. 1, 316325.

Haytowitz, D.B and Mathews, R.E.H (1984). Composition of foods, vegetables and vegetable products, Raw, processed, prepared USDA Handbook. 8 - 11

Kochhar, S.L (1986). Okra (Lady's finger) In: Tropical crops, a textbook of economic Botany. Editor S.L Kochhar pp $263-264$.

Kono, K and Yoshida, $Y$ (1989) Current aspect of trace element research in environmental health. Bull Osaka Med Coll. 35 (1-2): 1-9 
Kotzekidou, P and Roukas, T (1986). Characterization and distribution of Lactobacilli during Lactic fermentation of okra Hibiscus Esculentus. Journal of Food Science 51: 623-628.

Maga, J. A. (1982). Phytate: Its chemistry, occurrence, food interaction, nutritional significance and methods of analysis. J. Agric. Food Chem. 30: 1-9

Oberleas D (1973) Phytates. In: Toxicants occurring naturally in foods. National Academy of Science, Washinton DC, 363-371

Oboh G (2006) Antioxidant properties of some commonly consumed and underutilised tropical legumes. European Food Research Technology 224: 61-65. DOI 10.1007/s00217-006-0289-x

Oboh G, Ekperigin, M.M and Kazeem M.I (2005) Nutritional and haemolytic properties of eggplants (Solanum macrocarpon) leaves. Journal of Food Composition and Analysis. 18, 153-160.

Oguntona, T (1998). Green leafy vegetables In: Quality of plant foods Editors: Osagie A.U and Eka O.U publisher; Post Harvest research unit. University of Benin, Benin City pp 120 - 130

Ola, F.L and Oboh G (2001) Nutrient distribution and zinc bioavailability estimation in some tropical edible mushrooms. Nahrung/Food 45 (1), 67-68

Omueti, O and Adepoju, E. (1988). Research Note: Preliminary Assessment of the effect of processing and storage on the quality of five local vegetables. Nigeria Food Journal. 6: $67-71$

Oseni, T.O (1990). Effect of Harvesting period on yield and quality of okra pod abelmoschus esculentus (L) (moench). Nigerian Food journal 8: 122-125.

Perkin-Elmer, (1982). Analytical Methods for Atomic Absorption Spectrophotometry. Perkin-Elmer Corp., USA.

SAS (2002). Statistical Analysis System Proprietary software. Release 8.3. SAS Institute Inc., Carry, NC

Schalau J (2002). Backyard Gardener. Available at http://ag.arizona.edu. /yavapai/anr/hort/byg/.

Siemonsma, J.S and Kouame, C. (2004) Abelmoschus Esculentus. In plant resources of tropical Africa 2 Vegetable. Editors Grubben G.J.H and Denton O.A Published by PROTA foundation Netherlands Pp 2129.

Sowunmi, O and Chukwudebe, A. (1979). The effect of Age at harvesting on the chemical composition of okra fruit. Abelmoschus esculentus. Rep. Nig stored. Prod. Res. Inst. 1979/80 (Issued in 1983) Pp 111-116.

Tindall, H.D. (1983) Vegetables in the Tropics A textbook of Agriculture. Editor H.D Tindall. Macmillan publisher. Pp 328. 